\title{
QUALITATIVE ANALYSIS OF PIGMENTS AND BINDERS IN PAINT COLORS USED IN "GVOZDEN" BY MIĆA POPOVIĆ
}

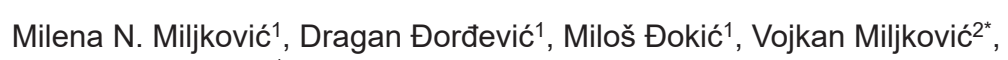
Kristina Stoilkovski ${ }^{1}$

\footnotetext{
${ }^{1}$ Faculty of Science and Mathematics, University of Niš, Niš, Serbia
}

2 Faculty of Technology, University of Niš, Leskovac, Serbia

The identification of pigments and binders in the samples of painting colors used during the creation of the painting "Gvozden" by a Serbian painter Mića Popović is presented in this work. The purpose of the research was the identification of basic components of painting colors in order to perform more efficient restoration of damaged paintings. In order to identify binders, FTIR spectroscopic analysis was performed; meanwhile, SEM-EDS method was used for the determination of pigments. Binding materials (identified using FTIR) based on easily dried plant oils were used during the creation of "Gvozden" and the preparation of painting colors. On the other hand, the most abundant pigments in the samples of painting colors (zinc and cadmium sulfides, barium sulfate, titanium and chromium oxide, mixed oxide of cobalt and aluminum, and calcium carbonate) were shown as results of SEM-EDS analysis.
(ORIGINAL SCIENTIFIC PAPER) UDC 667.633.2:543.4

Keywords: FTIR; SEM-EDS; Gvozden; pigments; binders

\section{Introduction}

Very often it is necessary for conservators to identify complex natural materials used in the production of artistic works. These data are useful for conservation and understanding of cultural events and painting techniques which have changed a lot during history . In order to obtain necessary data on the painting technique of some period, different sources must be combined: written statements by the artist or their contemporaries, art technological study of painting and chemical analysis.

Binding materials bind the particles of pigments, and also the pigments with the base to which the painting colour is applied. Mostly binders are macromolecular organic compounds of plant or animal origin and in general contain lipids, proteins, waxes, polysaccharides or resins [2].

On the other hand, minerals, clays and other inorganic compounds are often used as pigments and fillers in painting colors. Inorganic pigments are, in chemical structure, usually oxides, sulfides, sulfates, carbonates or oxyhydroxides of transition metals, where the effect of coloring depends on the structure of the pigment.

Techniques as infrared and Raman spectroscopy or gas chromatography-mass spectrometry find the application in investigations of artistic works. Non-destructive analysis by traditional macroscopic methods (X-radiography, near-infrared reflectance imaging, UV- visible fluorescence photography) can give the information on the support of the painting, compositional paint changes, under drawings, paint and varnish applications and restorations [3]. On the microscopic scale, materials can be identified by using Raman spectroscopy [4]; in macroscopic scale by using reflectance imaging spectroscopy [5], and X-ray fluorescence intensity mapping [6]. The methods offering 3D information are under investigation [7-9]. For years, infrared spectroscopy has represented the most abundant technique for analyzing painting materials $[2,10]$.

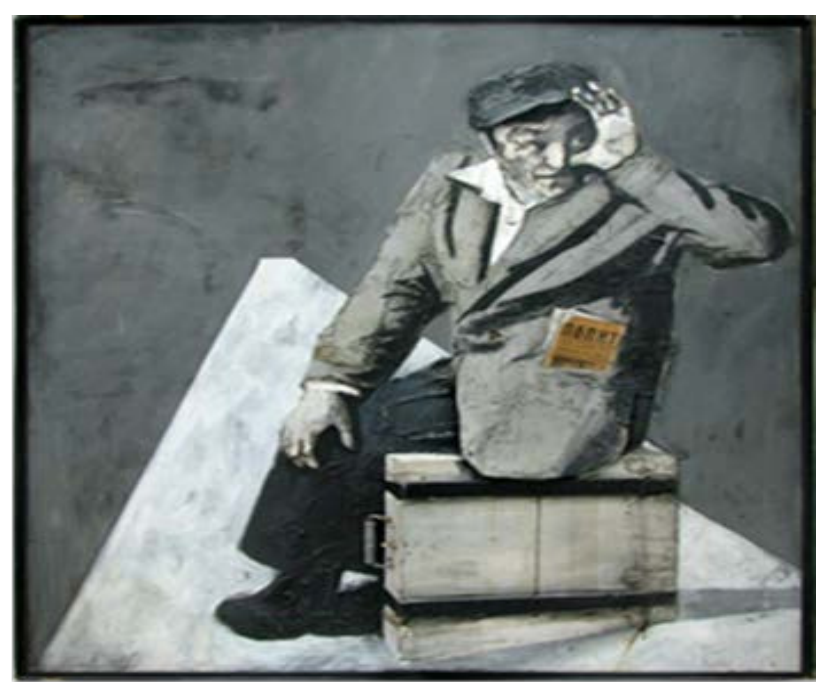

Figure 1. "Gvozden" by Mića Popović

\section{Experimental}

\section{Materials and methods-Sampling}

Solid samples of painting colors were taken from the surface of painting (Figure 1) by the professional conservator of the gallery "Serbia", Niš. Four samples were got

\footnotetext{
* Author address: Vojkan Miljković, Faculty of Technology, University of Niš,

Bulevar Oslobođenja 124, 16000 Leskovac , Serbia

E-mail: vojkanmm_serbia@yahoo.com

The manuscript received: April, 25, 2017.

Paper accepted: May,22, 2017.
} 
from different positions of the painting in order to make the analysis of the pigment content is as complete as possible, taking into account that different colors dominate on different positions of the painting. Sampling was performed by using a scalpel mechanically separated sample of the color from the position for which it was thought that it would not undermine the integrity of the artwork. The size of the sample varied with repeated tests, and the average size of the samples were around 1-3 $\mathrm{mm}^{2}$. The process of sampling was repeated several times, because the samples were irreversibly changed during the preparation for one analysis, and it was impossible to use them for further analyses using another instrumental technique. The whole process of the multiple sampling was performed during several months. Afterwards, the sample was carefully transferred into a plastic container for keeping and transport of the sample.

Preparation of samples for FTIR spectroscopic analysis

The preparation of samples for FTIR spectroscopic analysis was performed in Spectroscopic Laboratory at Faculty of Technology in Leskovac. For the analysis of solid samples, the method of $\mathrm{KBr}$ pastille was chosen as the most appropriate.
Characterization of the samples was performed by recording FTIR spectra in the mid IR region $\left(400-4000 \mathrm{~cm}^{-1}\right)$ using one ray transmission FTIR spectrometer BOMEMHartman \& Braun MP Series 100 (Michaelson, Canada).

Preparation of samples for SEM and SEM-EDS analysis

The preparation of the samples for SEM and SEM-EDS analysis was performed at the Laboratory for Electron Microscopy at the Faculty of Medicine in Niš. The process consisted of gold deposition in the form of a thin film on the equal area of the samples to be conductive for the electron beam.

After finishing the preparation of the samples, SEM analysis of the surface was performed placing the samples into the scanning electron microscope JEOL JSM-5300 (Japan) (working potential $30 \mathrm{kV}$, depth of penetration of the electron beam $10 \mu \mathrm{m})$. The characteristics of surfaces were observed using different amplifications (x100, x1000, $\mathrm{x} 2000$ ) and then photographed.

Afterwards, it was continued with SEM-EDS analysis for which further preparation was not necessary. The analysis was performed using the same scanning microscope, but with a different detector-Linx Analytical QX 2000.
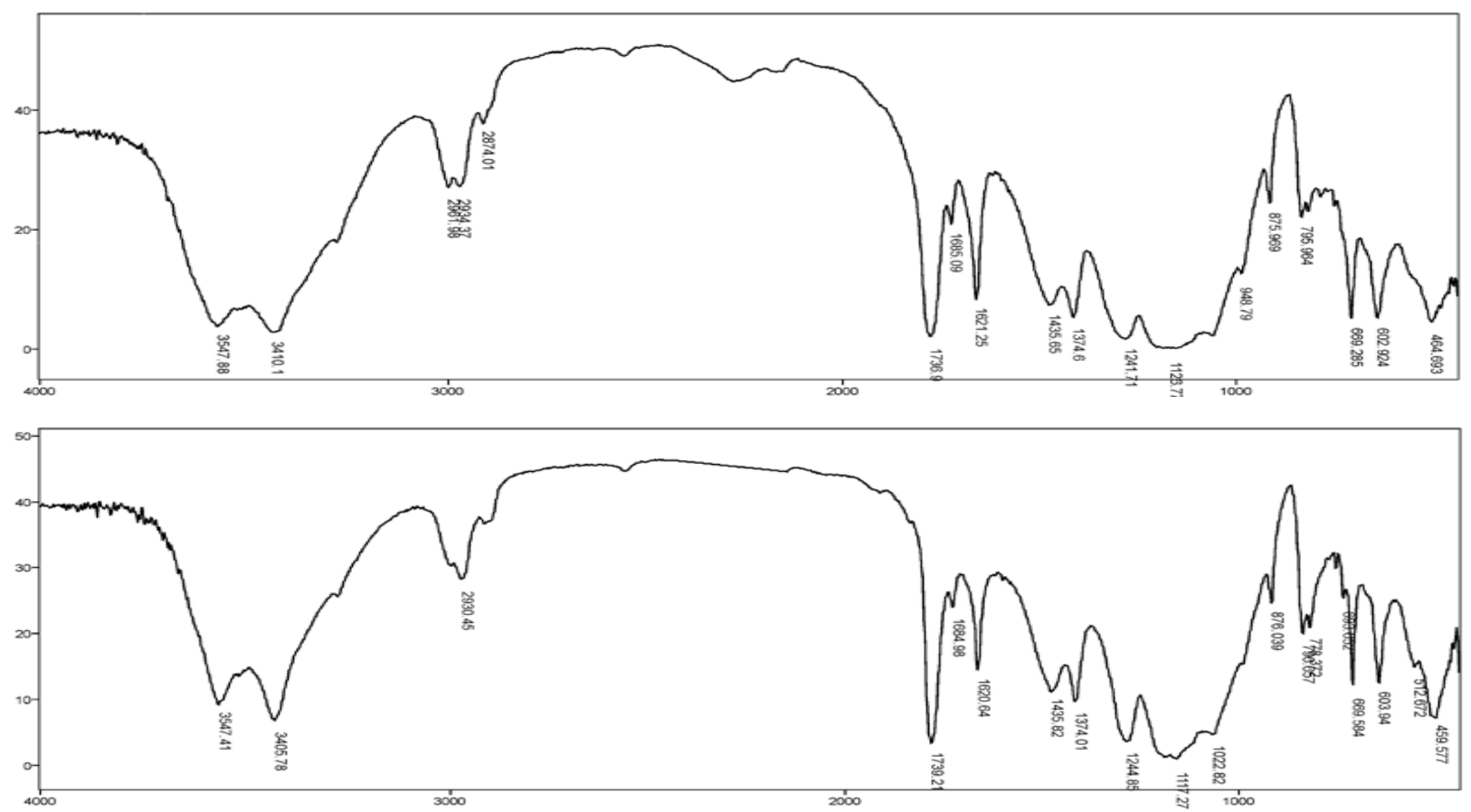

Figure 2. IR spectra of the samples of painting colors a) b)

\section{Results and discussion}

FTIR spectroscopic analysis

Two samples of painting colors were prepared and used in a spectroscopic analysis. Spectra are presented in Figure 2. The comparison of the FTIR spectra samples revealed that they are very similar, which means that the same binder was used in the creation and preparation of painting colors. The presence of the organic material in both samples was characterized by maximums around
$3000 \mathrm{~cm}^{-1}$, belonging to aromatic and unsaturated stretching vibrations of $\mathrm{C}-\mathrm{H}$ groups.

From the FTIR spectrum (Fig. 2a), the presence of carbonyl group with the maximum at $1739 \mathrm{~cm}^{-1}$ was observed, while in the second sample (Fig. 2b) the presence of this group was characterized with the maximum at $1736 \mathrm{~cm}^{-1}$. These values of maximum absorption of carbonyl group correspond to the area of absorption of ester bound $\mathrm{C}=\mathrm{O}$ group. The absorption maximum at $1620 \mathrm{~cm}^{-1}$ (Fig. 2a) i.e. $1621 \mathrm{~cm}^{-1}$ (Fig. 2b) refers to the 
presence of $\mathrm{C}=\mathrm{C}$ bond in the molecule, and maximums present in IR spectra at approximately $1435 \mathrm{~cm}^{-1}$ and $1374 \mathrm{~cm}^{-1}$ originate from deformational $\mathrm{C}-\mathrm{H}$ vibrations (asymmetrical and symmetrical). Maximums presented in both spectra in the area $900-1200 \mathrm{~cm}^{-1}$ usually derived from stretching $\mathrm{C}-\mathrm{O}$ or $\mathrm{Si}-\mathrm{O}$ vibrations. However, a wide band is present in this area and it is more probable that it comes from $\mathrm{Si}-\mathrm{O}$ vibrations because silicon is present in the sample in the form of aluminosilicate of kaolinite $\left(\mathrm{Al}_{2} \mathrm{O}_{3}{ }^{*} \mathrm{SiO}_{2} * 2 \mathrm{H}_{2} \mathrm{O}\right)$.

A broad absorption band which is present in both spectra and appears at around 3547 and $3405 \mathrm{~cm}-1$ originates from $\mathrm{N}-\mathrm{H}$ stretching vibration of primary amino groups. This absorbing region is overlapped with the region of stretching $\mathrm{O}-\mathrm{H}$ vibration absorption, and the simultaneous identification of both functional groups is impossible. The presence of the primary amino group in the molecule is characterized by the existence of two narrow absorption maximums in the field $3100-3500 \mathrm{~cm}^{-1}$ [18] $\mathrm{O}-\mathrm{H}$ stretching vibration gives a wide band in the range of $3600-3700 \mathrm{~cm}^{-1}$. In comparison with it, $\mathrm{N}-\mathrm{H}$ vibrations gives a peak in the range between 3300 and $3400 \mathrm{~cm}^{-1}$. This absorption peak is usually a sharper peak than $\mathrm{O}-\mathrm{H}$ vibration, and thus can vary.

Revealing the presence of carbonyl ester and the presence of aromatic materials indicates that it is very likely that alkyd resin was used as a binding agent, a binder based on polyester of phthalic acid.
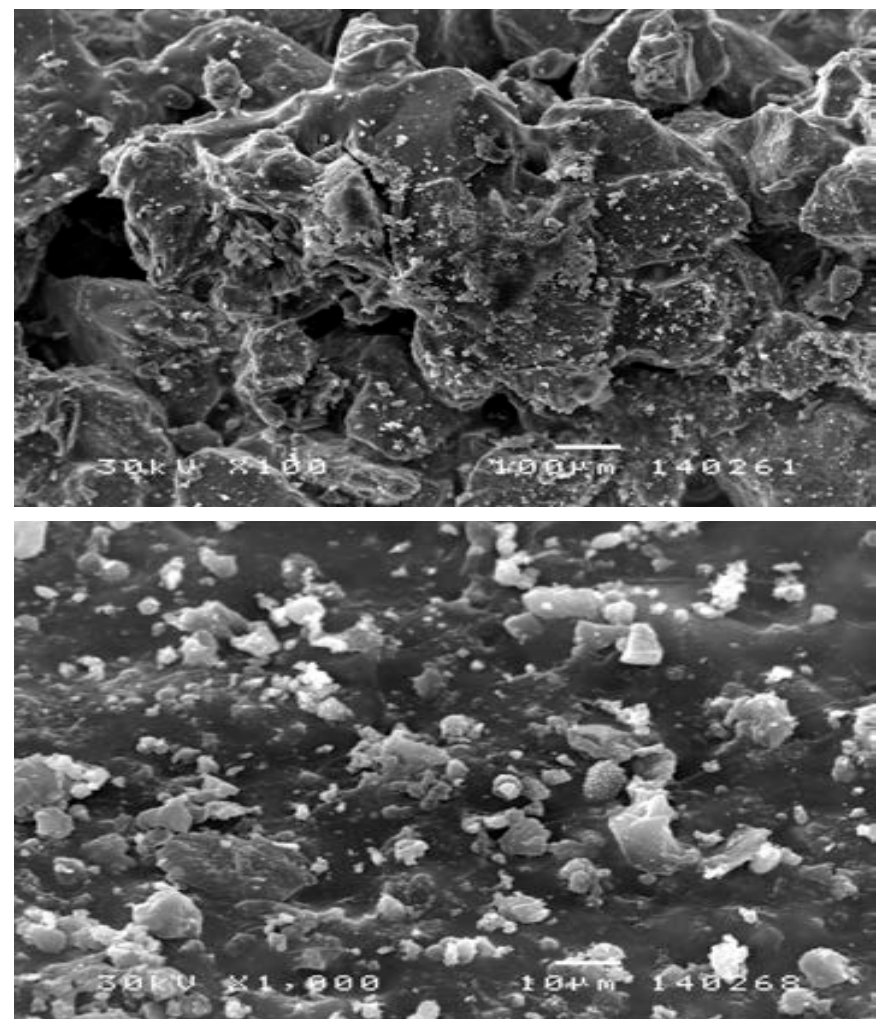

Figure 3. SEM photos of the micro surface of the sample a) x100 b) x1000 microscopic magnification.

\section{SEM-EDS analysis}

Two samples were analyzed and before the EDS analysis, photographing of micro surfaces of the samples was performed. Their pictures are presented in Figure 3. at a) $\times 100$ and b) $\times 1000$ microscopic magnification.

After the characterization and photographing of micro surfaces of the samples, SEM-EDS analysis was performed, and SEM-EDS spectra are given in Figure 4.
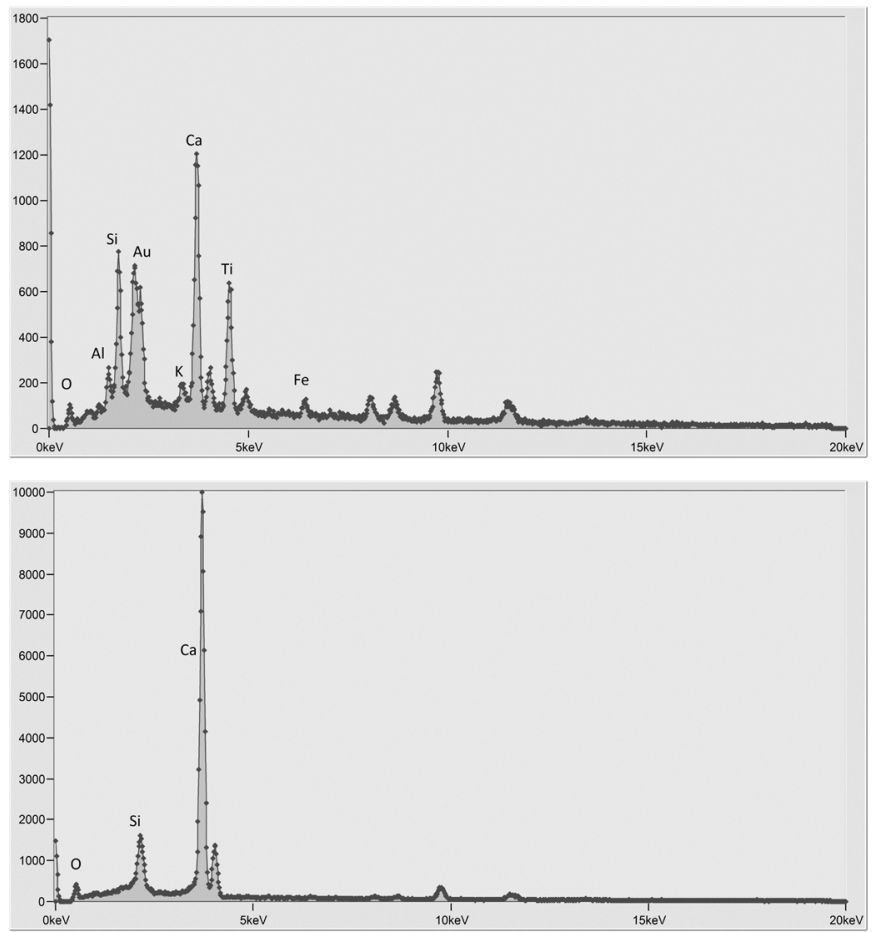

Figure 4. SEM-EDS spectra of the samples a) b)

From SEM-EDS spectrum of the first sample, it can be concluded that the most abundant elements are iron, aluminum, calcium, oxygen, potassium, silicon and titanium. Pigments made from these elements are $\mathrm{Fe}_{2} \mathrm{O}_{3}$ (red ocher), $\mathrm{Fe}_{2} \mathrm{O}_{3} \times \mathrm{nH}_{2} \mathrm{O}$ (yellow ocher) and $\mathrm{TiO}_{2}$ (white titan dioxide). Calcium is most likely present in the form of calcite, with the $\mathrm{CaCO}_{3}$ pigment. Silicon and aluminum are probably present in the form of aluminosilicate minerals kaolinite which has a role extender titanium dioxide and the modification of the level of the paint gloss. The presence of potassium is probably due to the application of colophony resin (soap) by a conservator before the SEM-EDS analysis was performed. Also, the presence of gold in the SEM-EDS spectrum is the result of the sample preparation.

Although the second color pattern, sampled from the painting second position, an SEM-EDS spectrum shows the presence of similar elements as in the previous sample. However, in this case the dominant peak comes from calcium, while the other two peaks come from the presence of silicon and oxygen. This suggests that the dominant pigment in the sample is actually $\mathrm{CaCO}_{3}$. 


\section{Conclusion}

During the creation of the painting "Gvozden" by Mića Popović, the bonding material applied during the preparation of the painting color was of the natural aliphatic/ aromatic polyester character. Based on the characteristic of the absorption maximum present in the FTIR spectra of color samples, and compared to the reference IR spectrum of the pure binding material, it can be concluded that the type of binding material is alkyl resins. SEM-EDS analysis showed that the samples of prevailing painting colors consist from oxide of iron and titanium pigments, aluminosilicon mineral kaolinite and calcite carbonate pigment.

\section{Acknowledgement}

Milena Miljković wishes to thank the Ministry of Education, Science and Technological Development of the Republic of Serbia (project no. 34020) for financial support.

\section{References}

[1] T. Reeves, R. S. Popelka-Filcoff, C. E. Lenehan, Towards identification of traditional European and indigenous Australian paint binders using pyrolysis gas chromatography mass spectrometry, Analytica Chimica Acta, 803 (1) (2013), 194-203.

[2] M. R. Derrick, D. Stulik, J. M. Landrey, Infrared Spectroscopy in Conservation Science, The Getty Conservation Institute, Los Angeles, 1999, 95-113.
[3] B. Steward, Analytical techniques in materials conservation, Wiley, New York, 2007.

[4] R. J. Clark, Raman microscopy as a structural and analytical tool in the fields of art and archaeology, J. Mol. Struct. 834-836 (2007) 74-80.

[5] K. A. Dooley, S.Lomax, J. G. Zeibel, C. Miliani, P. Ricciardi, A. Hoenigswald, M. Loew. J. K. Delaney, Mapping of egg yolk and animal skin glue paint binders in Early Renaissance paintinigs using near infrared reflectance spectroscopy, Analyst (London) 138 (2013) 4838-4848.

[6] J. Dik, K. Janssens, G. Van Der Snickt, L. van der Loeff, K. Rickers, M. Cotte, Visualizattion of a lost painting by Vincent van Gogh using synchrotron radiation based X-ray fluorescence elemental mapping, Anal. Chem. 80 (2008) 6436-6442.

[7] B. Kanngießer, W. Malzer, I. Mantouvalou, D. Sokaras, A. G. Karydas, A deep view in cultural heritage- Conical micro X-ray spectroscopy for depth resolved elemental analysis, Appl. Phys. A Mater. 106 (2012) 265-277.

[8] P. Targowski, M. Iwanicka, Optical Coherence Tomography: its role in the non-invasive structural examination and conservation of cultural heritage objects- a review, Appl. Phys. A. Mater. 106 (2012) 265-277

[9] A. J. L. Adam, P. C. M. Planken, S. Meloni, J. Dik, TeraHertz imaging of hidden paint layers on canvas, Opt. Express 17 (2009) 3407-3416

[10] F. Casadio, L. Toniolo, The analysis of polychrome works of art: 40 years of infrared spectroscopic investigations, J. Cult. Herit. 2 (2001) 71-78.

Izvod

\section{KVALITATIVNA ANALIZA PIGMENATA I VEZIVNIH MATERIJALA PRISUTNIH U SLIKARSKIM BOJAMA UMETNIČKE SLIKE "GVOZDEN" AUTORA MIĆE POPOVIĆA}

Milena N. Miljković1 ${ }^{\text {, Dragan Đorđević }}{ }^{1}$, Miloš Đokić1 ${ }^{1}$ Vojkan Miljković ${ }^{2}$, Kristina Stoilkovski ${ }^{1}$

\footnotetext{
${ }^{1}$ Prirodno-matematički fakultet, Univerzitet u Nišu, Niš, Srbija

${ }^{2}$ Tehnološki fakultet, Univerzitet u Nišu, Leskovac, Srbija
}

Cilj ovog rada je identifikacija pigmenata i vezivnih materijala prisutnih u slikarskim bojama umetničke slike istaknutog srpskog umetnika Miće Popovića. U tu svrhu su uzorci slikarskih boja adekvatno pripremljeni i analizirani metodama infracrvene spektroskopije i skenirajuće elektronske mikroskopije. Rezultati istraživanja (primenom IR spektroskopije) su pokazali da su dominantne vezivne organske materije korišćene prilikom pripreme slikarskih boja bila biljna ulja za stvaranje umetničke slike,,Gvozden“ autora Miće Popovića. Sa druge strane, elementalna SEM-EDS analiza je pokazala da su u uzorcima slikarskih boja prevashodno zastupljeni oksidni pigmenti (oksidi titana, gvožđa, aluminijuma, kalcijuma, itd.), koji ulaze u sastav alumosilikata ali i sulfidni pigmenti (sulfidi kadmijuma i arsena).
(ORIGINALNI NAUČNI RAD)

UDK 667.633.2:543.4

Ključne reči: IR spektroskopija, SEM-EDS, identifikacija, pigment, veziva. 